\title{
Hydrogeology of the Basin Granitoids in the Sekyere South District of Ashanti Region, Ghana
}

\author{
A. Ewusi, J. Seidu \\ Geological Engineering Department, University of Mines and Technology, Tarkwa, Ghana \\ Email: aewusi@umat.edu.gh
}

How to cite this paper: Ewusi, A. and Seidu, J. (2018) Hydrogeology of the Basin Granitoids in the Sekyere South District of Ashanti Region, Ghana. Journal of Geoscience and Environment Protection, 6, 252-263.

https://doi.org/10.4236/gep.2018.64015

Received: March 2, 2018

Accepted: April 10, 2018

Published: April 13, 2018

Copyright $\odot 2018$ by authors and Scientific Research Publishing Inc. This work is licensed under the Creative Commons Attribution International License (CC BY 4.0).

http://creativecommons.org/licenses/by/4.0/

\begin{abstract}
The hydrogeology of the Basin Granitoids in the Sekyere South District of Ashanti Region of Ghana has been evaluated applying the electrical resistivity imaging (ERI) geophysical technique and pumping test analysis. The ERI was conducted to obtain information on resistivity distribution for groundwater accumulation and pumping test was used to obtain transmissivity and sustainable yields of boreholes. Results from the ERI technique show that the general resistivity distribution in the area is between (20 - 4000) $\Omega$-m and the resistivity range that is related to groundwater occurrence is between $(50-300) \Omega-m$ for the weathered and (100 - 600) $\Omega-\mathrm{m}$ for the fractured granitic rocks. The aquifers are generally shallow to medium depth and where resistivities of the aquifer zones are less than $400 \Omega-\mathrm{m}$ in the fresh granites, high yields are likely to be attained. Pumping test also revealed that transmissivity values range between $(5.89-43)$ $\mathrm{m}^{2} /$ day, with sustainable yields ranging between $50-380 \mathrm{~m}^{3} /$ day. These results suggest that boreholes in the area will be sustainable for domestic supplies.
\end{abstract}

\section{Keywords}

Electrical Resistivity Imaging, Groundwater Potential, Transmissivity

\section{Introduction}

Communities in the Sekyere South District of the Ashanti Region of Ghana experience water shortages because majority of the existing water supply systems are primarily based on ephemeral surface water sources that are fed by rainfall but not evenly distributed all-year round. The current situation is that most communities rely solely on boreholes fitted with hand pumps and these point-source boreholes are always crowded during peak hours (6:00 am - 7:30 am) of fetching. The development of groundwater resources for mechanized piped water system with borehole sources of yields greater than 40 litres per 
minute $(40 \mathrm{l} / \mathrm{m})$ is seen as the most efficient and cost effective way to increase access to safe water in the area to meet coverage targets. However, the rocks in the area comprise exclusively granites which generally have low groundwater potential unless they are weathered and/or fractured. These granitic rocks are usually devoid of primary porosity but secondary porosity is developed as a result of weathering and fracturing [1]. Moreover, weathering depths in the Granitoids are shallow [2].

The success of borehole drilling in granitic terrains therefore depends on the number and aperture of fractures that a borehole intercepts because their presence in a geological medium can influence its hydrogeological characteristics. A good borehole is one which penetrates a significantly thick weathered overburden and also intercepts fractures in the underlying bedrock [3]. The electrical resistivity imaging (ERI) has become popular for groundwater surveys in Ghana and has been found to be effective for demarcating such features as fractures in bedrock as well as overburden thickness [4] which are good indicators for groundwater accumulation. In cases where the ERI technique has been employed, borehole success rates of drilling have increased considerably [2] [4]. Pumping test has been used to obtain the hydraulic characteristics of the rocks in the area. This paper summarizes results of hydrogeophysical and hydrogeological evaluation of the granitic rocks of the Sekyere South District using ERI and pumping test analyses.

\section{The Study Area}

Sekyere South District is one of the twenty seven administrative districts in the Ashanti Region of Ghana; with a total land area of $584 \mathrm{~km}^{2}$ and represents about $2.4 \%$ of the total landmass of the Ashanti Region of Ghana. The district lies between latitude $6^{\circ} 50^{\prime} \mathrm{N}$ and $7^{\circ} 10^{\prime} \mathrm{N}$ and Longitude $1^{\circ} 40^{\prime} \mathrm{W}$ and $1^{\circ} 25^{\prime} \mathrm{W}$. It shares boundaries with Ejura Sekyedumase to the north, Mampong Municipal to east, Sekyere East and Kwabre east to south and Afigya Kwabre to the west. The vegetation of the district can be best described as moist semi-deciduous. Greater part of the district falls within a dissected plateau with heights between (800 to 1200) $\mathrm{m}$ above sea level. The only high land can be found in the northern portion which happens to be the Mampong Escarpment stretching from Jamasi to Boanim. Major rivers in the district includes the Offin, Oyon and Abankro [5].

\subsection{Geology and Hydrogeology}

The Sekyere South District is underlain by the Basin Granitoids (Figure 1). These granitic rocks are related to the later stages of the Eburnean orogeny at or after the end of the Birimian deposition. They are often associated with schists and gneisses and intrude the Birimian meta-sedimentary rocks [2] [6]. The Basin Granitoids underlying the area are normally well foliated, often migmatic, potash rich Granitoids which take the form of muscovite-biotite granite, granodiorite, porphyroblastic biotite gneiss, aplites and pegmatites. The Granitoids are 


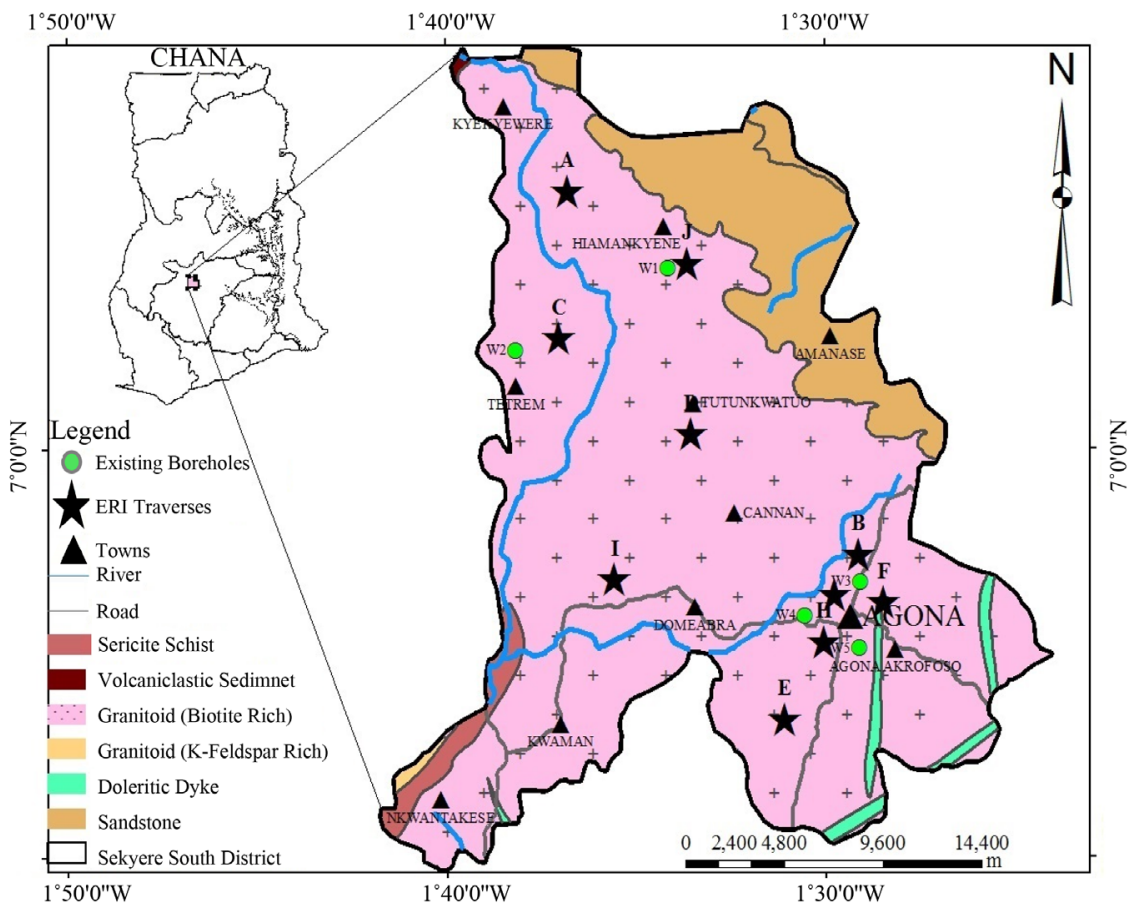

Figure 1. Geological Map of the Study Area showing Locations of ERI Profiles and Existing Boreholes [8].

characterised by the presence of many enclaves of schists and gneisses [6].

One characteristic of these rocks is that it is not inherently permeable, but secondary permeability and porosity have developed as a result of fracturing and weathering. The hydraulic potential depends on the degree of fracturing and the potential recharge of the aquifer, which is directly related to the annual rainfall and water streaming.

Borehole information shows that, the depth to bedrock is shallow, ranging between $13-20 \mathrm{~m}$ with an average of $17 \mathrm{~m}$. Fractures that aid in groundwater accumulation are not well developed and this therefore results in low groundwater potential in the area [7].

\subsection{Water Resources}

The Sekyere South District located on a gentle hill is bounded to the north and south by two river valleys and is drained mainly by the Offin River to the west. Other streams which are tributaries to the Offin River such as Awyon and Bentiko are located in the northern and southern parts of Agona. The Kunkum stream flow from the east towards the west. There are other smaller streams that drain the area which flow from the north towards the south.

The Sekyere South District depends on boreholes (both mechanized and hand pump) installed for their water supply. The mechanized systems are located in the small towns including Agona and Jamasi and individual homes. The mechanized wells have an average yield of about $10 \mathrm{~m}^{3} / \mathrm{hr}$ [7]. 
Aquifers can be obtained in the weathered and fractured granitic rocks which underlie the area. Boreholes obtaining its yields from both the weathered and the fractured zones are preferred for sustainable groundwater abstraction [7]. Recharge to the aquifers is from direct rainfall and the ephemeral streams in the area. The annual rainfall ranges between $(1250-2000) \mathrm{mm}$. This suggests that there is a good groundwater recharge from precipitation.

\section{Materials and Methods}

\subsection{Field Geophysical Survey}

Geophysical field measurements were carried out on pre-defined profiles using the electrical resistivity imaging (ERI) technique. These profiles were selected based on reconnaissance survey that was carried out. The profiles were selected to intercept the probable lineaments from air photo interpretation of the area. Measurements were carried out on eight profiles. Standard $400 \mathrm{~m}$ length profile measurements were carried out on each profile using the ABEM Terrameter SAS 4000. Measurement on a profile comprised the following:

- Profile with 64 electrodes and $5 \mathrm{~m}$ spacing in the inner (100 to $300 \mathrm{~m}$ ) cable loop and $10 \mathrm{~m}$ spacing at the outer ( 0 to $100 \mathrm{~m}$ and 300 to $400 \mathrm{~m}$ ) cable lengths [4].

- Measurement configuration was the Wenner Long (WL) and the Wenner short (WS).

The ABEM Terrameter SAS 4000, which employs the static Lund automatic resistivity imaging systems suitable for high-resolution 2-D resistivity surveys and provides detailed information both laterally and vertically along the profile to investigate complex geological structures [9] [10] was employed. The resistivity data from the profile were inverted using the RES2DINV software to obtain the true 2-D resistivity model section [11]. Blue colors are generally used to represent areas of low resistivity and red colors identify relatively higher resistive areas [4].

The 2-D model used for the inversion process also obeys the classical law of the resistivity theory and so the proposed model is one of the solutions and not the ultimate unique situation [12]. The geo-electrical model obtained by the inversion process is generally not a geological section and so interpretation must be carried out based on the considerations of the prevailing field geological conditions [12].

\subsection{Evaluation of Existing Borehole by Pumping}

Pumping test analysis was carried out on five (5) existing boreholes in the area. They were redeveloped by airlifting for the purpose of cleaning and establishing airlift yields since there were no available records.

\subsubsection{Step Test}

A four-step performance test was carried out on five boreholes in the area. The 
purpose of the step-test was to determine the relationship between drawdown and yield for the boreholes in the short term pumping situation and to select the yield for the constant discharge test. The discharges for the steps were $25 \%, 50 \%$, $75 \%$ and $100 \%$ of the airlift yield respectively. The rate for the constant discharge was determined from projecting step-test data over the scheduled 24-hour pumping period and assessing the drawdown after which an appropriate discharge rate was then selected.

\subsubsection{Constant Discharge Test}

A twenty-four (24)-hour pumping and twelve (12)-hour recovery was adopted.

Water level measurements were taken in accordance with the recommended guideline time schedule during pumping and recovery [7]. The water level measurements taken were plotted against time on a semi logarithmic graph. From the graph, the transmissivities were estimated using the Cooper-Jacob method. The dynamic water level at the end of twenty four (24) hours was recorded. The boreholes located close to each other were tested concurrently to directly incorporate anticipated interference effects due to proximity.

\subsubsection{Sustainable Yield}

Sustainable yield approach [13] [14] [15] is used because it reserves a fraction of safe yield for the benefit of the surface water bodies even though there is a lack of consensus as to what percentage of safe yield should constitute sustainable yield [16].

The Modified Nonequilibrium Equation [17] is used to estimate the maximum sustainable yield that can be pumped from a well in order to develop a pumping water level that does not exceed the maximum allowable drawdown in the well after 300 days of pumping. It is assumed that recharge occurs during the remaining 65 days of the hydrological year [7].

\section{Results and Discussion}

\subsection{Hydrogeophysical Evaluation}

Figures 2-9 give results of the ERI on profiles $\mathrm{A}$ to $\mathrm{H}$ in the area and the information on these profiles are summarized in Table 1.

It is observed from the pseudo-sections that the area is underlain by relatively high resistive rocks. The areas with very low resistivity distribution in such geology are therefore regarded as potential targets for groundwater accumulation. The profile $\mathrm{A}$ is carried out to calibrate one of the existing boreholes (station 200 $\mathrm{m}$ ) in the area (Figure 2) to serve as a guide in the analysis.

The resistivity distribution of the area varies between $(50-1200) \Omega-\mathrm{m}$. The borehole $(\mathrm{BH})$ located at station $200 \mathrm{~m}$ is obtaining its yield from the low resistivity distribution less than $500 \Omega$-m to a depth of $20 \mathrm{~m}$. However, a possible borehole location at station $140 \mathrm{~m}$ which has resistivity values less than $150 \Omega$-m at depth $(12-20) \mathrm{m}$ could have resulted in a higher yield. Stations $(0-160) \mathrm{m}$ 
depicts low resistivity zones between the depths of $(5$ - 30) $\mathrm{m}$ which reduces in depth along the profile to station $400 \mathrm{~m}$. The depths range has been able to produce successful boreholes in such granite geology.

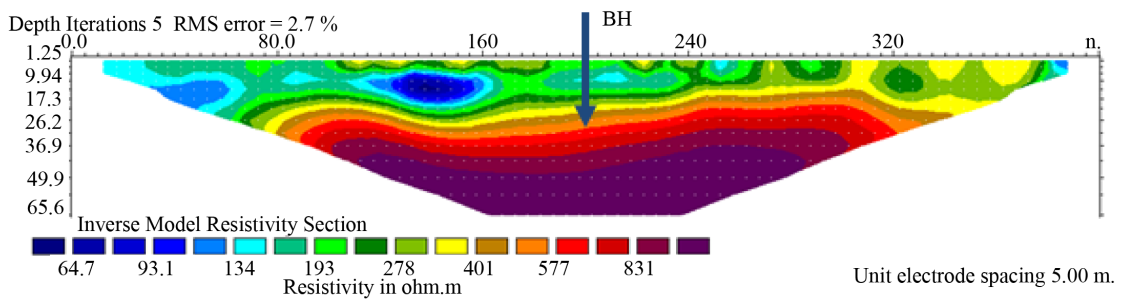

Figure 2. ERI Profile A.

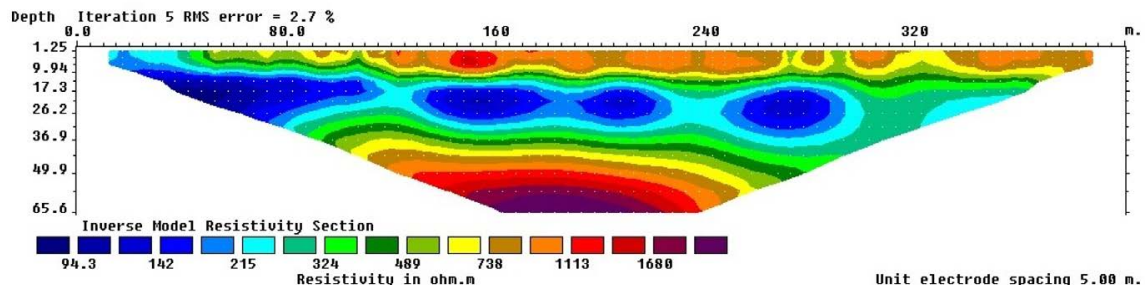

Figure 3. ERI for Profile B.

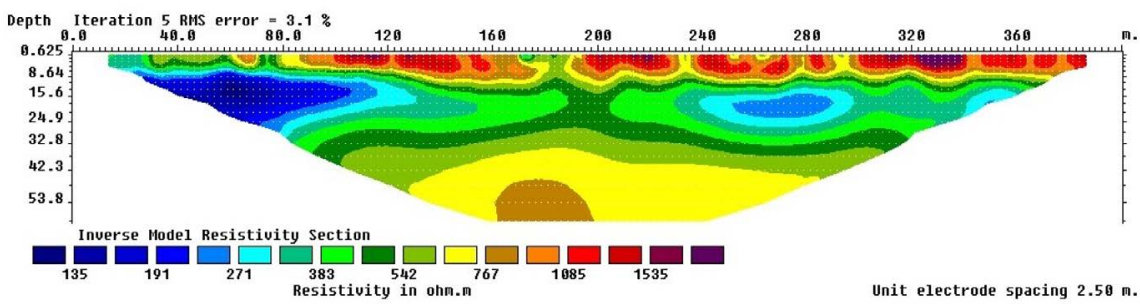

Figure 4. ERI for Profile C.

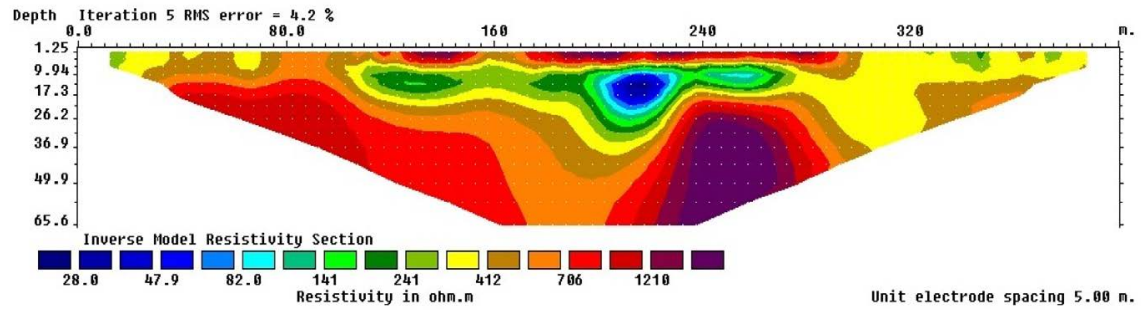

Figure 5. ERI for Profile D.

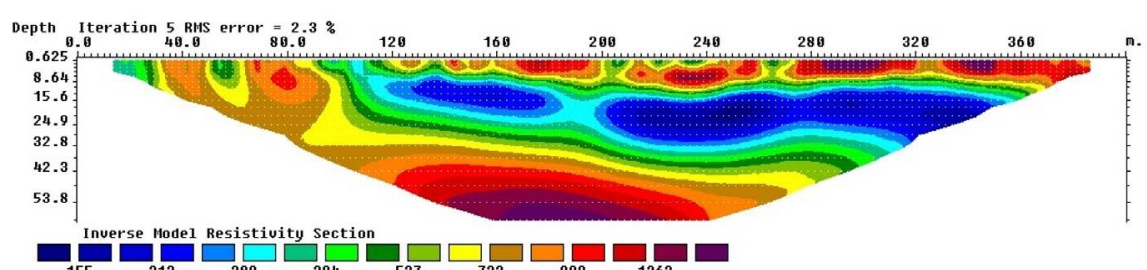

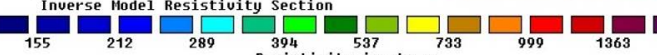

Unit electrode spacing $2.50 \mathrm{~m}$

Figure 6. ERI for Profile E. 


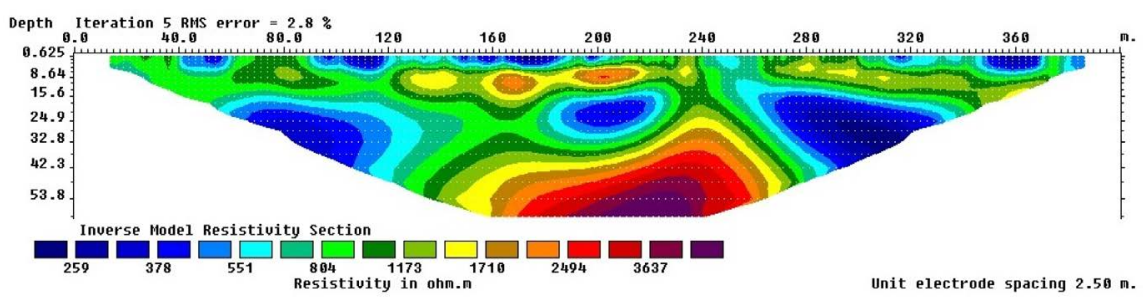

Figure 7. ERI for Profile F.

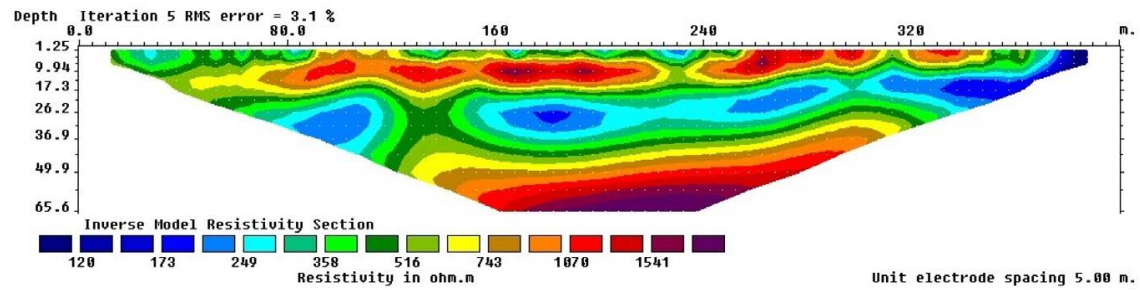

Figure 8. ERI for Profile G.

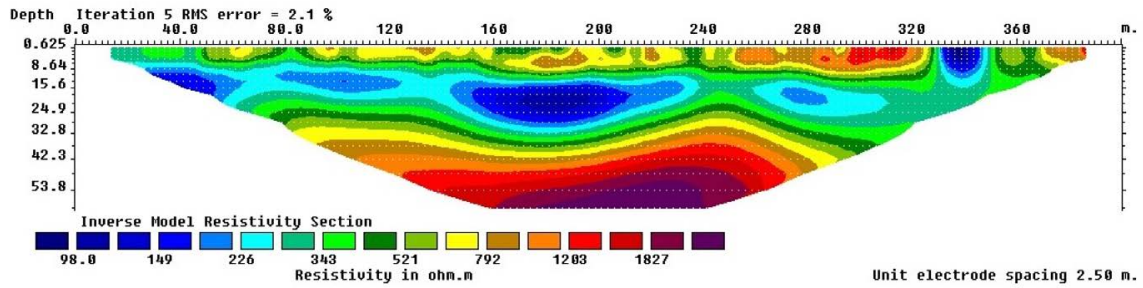

Figure 9. ERI for Profile H.

Table 1. Summary of profile locations.

\begin{tabular}{ccccc}
\hline \multirow{2}{*}{ Profile } & \multicolumn{2}{c}{ Start } & $\mathrm{X}(\mathrm{m})$ & $\mathrm{Y}(\mathrm{m})$ \\
\cline { 2 - 5 } & $\mathrm{X}(\mathrm{m})$ & $\mathrm{Y}(\mathrm{m})$ & 659,164 & 782,049 \\
$\mathrm{~A}$ & 658,963 & 782,396 & 667,703 & 769,204 \\
B & 667,309 & 769,272 & 652,944 & 778,693 \\
C & 652,720 & 779,020 & 659,416 & 774,990 \\
D & 659,154 & 774,687 & 663,909 & 762,182 \\
E & 663,741 & 761,819 & 668,644 & 766,726 \\
F & 668,519 & 767,106 & 666,431 & 767,128 \\
G & 666,162 & 767,425 & 666,051 & 765,359 \\
H & 665,652 & 765,323 &
\end{tabular}

The resistivity distribution of profile B varies between (80 - 2000) $\Omega$-m (Figure 3). The profile shows three distinct resistivity layers. The first resistivity layer occurs to a depth of $9 \mathrm{~m}$ below the surface with resistivity values ranging from (300 - 1000) $\Omega-\mathrm{m}$. The second layer has low resistivity values (80 - 250) $\Omega$-m with a thickness of $25 \mathrm{~m}$. High resistivity of rocks above $1000 \Omega-\mathrm{m}$ is observed after $45 \mathrm{~m}$. 
Along profile $\mathrm{C}$, it is observed that high resistivity values (>1000 $\Omega-\mathrm{m}$ ) occurs close to the surface (Figure 4). This is an indication that the Granitoids outcrop close to the surface in the area. After a depth of $9 \mathrm{~m}$ on the modeled section, a low resistivity layer between $(100-300) \Omega-\mathrm{m}$ is located at stations $(0-120) \mathrm{m}$ and $(240-300) \mathrm{m}$. These could indicate water bearing zones. Resistivity values between (500 - 800) $\Omega$-m are observed after a depth of $30 \mathrm{~m}$.

Profile D has a resistivity distribution of $(20-1500) \Omega-\mathrm{m}$. Along the profile, three distinct resistivity regions are observed (Figure 5). Regions with very low resistivity between $(20-300) \Omega-\mathrm{m}$ are observed between stations $100-275 \mathrm{~m}$, and are located between depths of $(8-30) \mathrm{m}$. Regions with moderate resistivity (400 - 800) $\Omega$-m surrounds the low resistivity areas. Resistivity values greater than $1000 \Omega$-m are observed between stations (235 - 275) $\mathrm{m}$ and with a thickness of $33 \mathrm{~m}$.

Three distinct horizontally layered resistivities are observed beneath profile $\mathrm{E}$ (Figure 6). The first resistivity layer has values between $(100-400) \Omega$-m, which occurs between depths of $(8-30) \mathrm{m}$. The second resistivity layer occurs between depths of $(30-42) \mathrm{m}$ and has resistivity values ranging between (500 - 900) $\Omega$-m. Resistivity values greater than $1000 \Omega$-m are observed below a depth of 45 $\mathrm{m}$ and also outcrops close to the surface.

Three significant low resistivity anomalous zones were observed beneath profile $\mathrm{F}$ at stations $85 \mathrm{~m}, 205 \mathrm{~m}$ and $310 \mathrm{~m}$ (Figure 7). These anomalies represent weak zones which may be suitable for the drilling of a productive borehole. The depths at which they occur are in the range $(10-40) \mathrm{m}$ which is similar to anomalies observed on profiles $\mathrm{B}$ and $\mathrm{E}$. The resistivity distribution of the area varies between (200 - 3800) $\Omega$-m.

Along profiles $\mathrm{G}$ and $\mathrm{H}$, low resistivity zones (100 - 300) $\Omega$-m are observed at depths $(8-30) \mathrm{m}$. These zones are suspected to be zones of weakness and therefore suggest water bearing zone. Profiles $G$ and $H$ have resistivity distribution of values between (100 - 2000) $\Omega$-m (Figure 8 and Figure 9).

Generally, the resistivity distribution of the area ranges between $90-4000$ $\Omega$-m with the low resistivity ranges ( $90-400) \Omega$-m occurring at relative depths of between $8-20 \mathrm{~m}$. The modeled sections revealed that areas where low resistivity values forms bowl-shape which are underlain by high resistivity distribution yield water [4]. The high resistivity value which underlies the bowl-shape serve as an impermeable unit which retains the water. From the profiles, it can be deduced that groundwater in the area is controlled by the overburden thickness and fractures which have very low resistivity distribution. Information on resistivity distribution related to groundwater occurrence is summarized in $\mathrm{Ta}$ ble 2 . The groundwater potential has been categorized into very good, good and poor potential according to the resistivity distribution of the Granitoids in the area. In the weathered rock, resistivity of (50 - 300) $\Omega$-m are likely to yield water, (100 - 600) $\Omega-\mathrm{m}$ in the fractured rocks has a very high probability for groundwater occurrence and resistivity $>1500 \Omega$-m are likely to result in dry wells, thus low groundwater potential. 
Table 2. Resistivity distribution for groundwater accumulation.

\begin{tabular}{|c|c|c|}
\hline Rock & Resistivity $(\Omega-\mathrm{m})$ & Hydrogeological Significance \\
\hline Weathered granite & $50-300$ & $\begin{array}{l}\text { Good groundwater potential, occurs at shallow } \\
\text { depth suitable for domestic supply }\end{array}$ \\
\hline Fractured granite & $100-600$ & $\begin{array}{l}\text { Very good groundwater potential with high yields } \\
\text { suitable for mechanized domestic purposes }\end{array}$ \\
\hline Fresh granite & $>1500$ & $\begin{array}{l}\text { Poor groundwater potential, occurs beyond } \\
\text { depth of } 40 \mathrm{~m}\end{array}$ \\
\hline
\end{tabular}

\subsection{Pumping Test Analysis of Existing Boreholes}

\subsubsection{Pumping Test}

Practically there was a consistent reduction in water level for the whole twenty-four (24)-hour period of pumping. The average drawdown per log cycle that was recorded from the constant discharge rate test is $2.99 \mathrm{~m}$. The maximum and minimum transmissivities recorded are $5.98 \mathrm{~m}^{2} /$ day and $43.31 \mathrm{~m}^{2} /$ day respectively. No interferences were obtained which suggest that the aquifers are not connected. Results from the pumping test on the five (5) boreholes are summarized in Table 3.

The calculated percentage of the twelve (12)-hour recovery period was above 99\% in all cases. The recovery was obtained by comparing the water level 12 hours after pump shutdown to the static water level (SWL). These are very good recovery rates for the applied discharge rates. The well-replenishment potential is high, suggesting good sustainability at the recommended rates. This is further supported by thick overburdens offering high storage potential.

\subsubsection{Sustainable Yield and Transmissivity}

Sustainable yield of boreholes vary within the area. Also, the drawdown was low indicating that pumping can be sustained and that aquifers can recuperate as reported by [18]. The maximum and minimum sustainable yields recorded are $380 \mathrm{~m}^{3} /$ day and $50 \mathrm{~m}^{3} /$ day (Table 3 ). Boreholes in the area are classified as successful from the yields obtained. The Ghana Community Water and Sanitation Agency define a successful borehole as one which has a yield of $18.72 \mathrm{~m}^{3} /$ day (13 $1 / \mathrm{min}$ ) for hand pump installation [4]. In order to meet target for a mechanised borehole a yield of greater $57 \mathrm{~m}^{3} /$ day $(40 \mathrm{l} / \mathrm{min})$ is appropriate.

Transmissivity magnitude and its relation with groundwater supply modified after [19] is presented in Table 4. Transmissivity values obtained from the five (5) boreholes in Sekyere South District show that the area can be classified as intermediate (Table 4), which suggest that boreholes are sustainable if it is used for local water supplies and pumped at the sustainable yields. However, transmissivity of borehole W1 $\left(5.98 \mathrm{~m}^{2} /\right.$ day $)$ shows that it can only serve for very limited withdrawals for the use of small communities.

Boreholes W3 and W4 are close to the stream that drain the area, and these boreholes recorded the highest transmissivities possibly because of recharge from the stream. This has been confirmed by studies from [2] in the Granitoids. 
Table 3. Summary of constant rate pumping test results.

\begin{tabular}{|c|c|c|c|c|c|}
\hline Pumping Test Details & W1 & W2 & W3 & W4 & W5 \\
\hline Borehole Depth (m) & 57 & 48.8 & 57 & 47 & 52 \\
\hline Discharge $\left(\mathrm{m}^{3} / \mathrm{d}\right)$ & 93.6 & 432 & 576 & 864 & 201.6 \\
\hline Static Water Level (m) & 1.25 & 4.15 & 2.39 & 4.35 & 6.28 \\
\hline Dynamic Water Level (m) & 25.4 & 28.15 & 17.21 & 15.9 & 31.45 \\
\hline Drawdown $(\mathrm{m}) / \log$ cycle & 2.87 & 2.78 & 3.44 & 3.65 & 2.23 \\
\hline Percentage recovery after 12 hours & 99.96 & 99.79 & 99.93 & 99.83 & 99.17 \\
\hline Transmissivity $\left(\mathrm{m}^{2} / \mathrm{d}\right)$ & 5.98 & 28.42 & 30.69 & 43.31 & 16.57 \\
\hline Estimated water level at the end of dry season (m) & 27.35 & 34.55 & 26.39 & 23.15 & 33.38 \\
\hline $\begin{array}{c}\text { Estimated Sustainable Yield at intermittent } 16 \\
\text { hours pumping per day }\left(\mathrm{m}^{3} / \text { day }\right)\end{array}$ & 50 & 280 & 350 & 380 & 110 \\
\hline
\end{tabular}

Table 4. Classification of transmissivity magnitude.

\begin{tabular}{|c|c|c|}
\hline $\begin{array}{l}\text { Transmissivity } \\
\left(\mathrm{m}^{2} / \text { day }\right)\end{array}$ & $\begin{array}{l}\text { Designation of T } \\
\text { Magnitude }\end{array}$ & Groundwater Supply Potential \\
\hline$>1000$ & Very high & Withdrawals of great regional importance \\
\hline $100-1000$ & High & Withdrawals of lesser regional importance \\
\hline $10-100$ & Intermediate & $\begin{array}{l}\text { Withdrawals for local water supply } \\
\text { (small communities, plants etc.) }\end{array}$ \\
\hline $1-10$ & Low & $\begin{array}{l}\text { Smaller withdrawals for local water supply } \\
\text { (private consumption) }\end{array}$ \\
\hline$<1$ & Very low & $\begin{array}{l}\text { Withdrawals for local water supply } \\
\text { with limited consumption }\end{array}$ \\
\hline
\end{tabular}

${ }^{*}$ T-Transmissivity (Modified after [19]).

\section{Summary and Conclusions}

Generally, the resistivity distribution of the study area ranges between (20 $4000) \Omega-m$. The low resistivity layers between (100 - 400) $\Omega$-m and occurs between depths of ( 8 - 25) $\mathrm{m}$ which are good indicators for groundwater accumulation and are most likely the water bearing zones. The average aquifer thickness is $18 \mathrm{~m}$. Groundwater in the area is controlled by the overburden and fractures.

The ERI technique has been successful in delineating aquifer horizons within a generally barren water-bearing lithology. Groundwater can be detected based on resistivity distribution. The ERI is effective in demarcating groundwater potential zones by differentiating the electrical resistivity at the subsurface. Weathered and fresh rocks on the profiles were clearly differentiated by different resistivities. The presence of a weathered and/or fractured zone is a factor in sitting a well. The research has proven that ERI is a cost effective approach in groundwater exploration.

Also groundwater in the district occurs at a relatively shallow depth with the potential water bearing zones occurring between depths of $(8-15) \mathrm{m}$ for weathered aquifers and $(20$ - 30) $\mathrm{m}$ for fractured aquifers. All the boreholes have ex- 
cellent recoveries (99\%) after pump shutdown. This shows that the boreholes are sustainable at the recommended sustainable yields. Transmissivity values obtained show that the boreholes in the area can be used for domestic purposes for individual homes and small town water supply schemes.

The results from this study could serve as a guide to groundwater exploration in the Granitoids in the area and similar geology.

\section{References}

[1] Singh, V.S., Krishnan, V., Sarma, M.R.K., Gupta, C.P. and Dhar, R.L. (1999) Hydrogeology of Limited Aquifer in a Granitic Terrain. Environmental Geology, 37, 1-2. https://doi.org/10.1007/s002540050364

[2] Ewusi, A. and Kuma, J.S. (2010) Calibration of Shallow Borehole Drilling Sites Using the Electrical Resistivity Imaging Technique in the Granitoids of Central Region, Ghana. Natural Resources Research, 20, 57-63. https://doi.org/10.1007/s11053-010-9129-6

[3] Louis, F.L., Louis, I.F. and Grambas, A. (2002) Exploring for Favourable Groundwater Conditions in Hardrock Environments by Resistivity Imaging Methods: Simulation Approach and Case Study Example. International Conference on Earth Science and Electronics, Istanbul, Turkey, 1-15.

[4] Ewusi, A., Kuma, J.S. and Voigt, H.J. (2009) Utility of the 2-D Multi-Electrode Resistivity Imaging Technique in Groundwater Exploration in the Voltaian Sedimentary Basin, Northern Ghana. Natural Resources Research, 18, 267-275. https://doi.org/10.1007/s11053-009-9102-4

[5] Osei, F.Y. (2011) Arsenic Levels in Borehole Water, Surface Water, Surface Water Sediments and Soil within $100 \mathrm{~m}$ Radius of Boreholes from Buruli Ulcer Endemic Areas in the Sekyere South District of Ashanti Region, Ghana. Unpublished MSc Thesis, Kwame Nkrumah University of Mines and Technology, Kumasi, Ghana.

[6] Kesse, G.O. (1985) The Mineral and Rock Resources of Ghana. A.A Balkema Publisher, Rotterdam, 610 p.

[7] Unihydro Report (2009) Agona Report: Sitting and Rehabilitation of Boreholes for the Subsequent Year Investment Programme (SYIP). Unpublished, 29 p.

[8] Ghana Geological Survey (2009) Geological Map of Ghana-1:1,000,000. Geological Survey Department, Accra, Ghana.

[9] Kirsch, R. and Yaramanci, U. (2009) Geoelectrical Methods, In: Kirsch, R., Ed., Groundwater Geophysics, Springer, Berlin Heidelberg, 85-117. https://doi.org/10.1007/978-3-540-88405-7_3

[10] Mohamed, S.E.J., Shaharin, I., Wan Nor Azim, S. and Puziah, A.L. (2012) Groundwater Resources Assessment Using Integrated Geophysical Techniques in the Southwestern Region of Peninsular Malaysia. Arabian Journal of Geosciences, 16.

[11] Loke, M.H. and Baker, R.D. (1996) Rapid Least-Squares Inversion of Apparent Resistivity Pseudosections by a Quasi-Newton Method. Geophysical Prospecting, 44, 131-152. https://doi.org/10.1111/j.1365-2478.1996.tb00142.x

[12] Ewusi, A. (2006) Groundwater Exploration and Management Using Geophysics: Northern Region of Ghana. Unpublished PhD Thesis, Bradenburg Technical University of Cottbus, Germany, $171 \mathrm{p}$.

[13] Alley, W.M. and Leake, S.A. (2004) The Journey from Safe Yield to Sustainability. Groundwater, 42, 12-16. https://doi.org/10.1111/j.1745-6584.2004.tb02446.x 
[14] Maimone, M. (2004) Defining and Managing Sustainable Yield. Groundwater, 42, 809-814. https://doi.org/10.1111/j.1745-6584.2004.tb02739.x

[15] Seward, P., Xu, Y. and Brendock, L. (2006) Sustainable Groundwater Use, the Capture Principle, and Adaptive Management. Water SA, 32, 473-482.

[16] Ponce, V. (2007) Sustainable Yield of Groundwater. California Department of Water Resources. http://gwsustainability.sdsu.edu

[17] Cooper, H.H. and Jacob, C.E. (1946) A Generalized Graphical Method for Evaluating Formation Constants and Summarizing Well Field History. American Geophysical Union Eos Transactions, 27, 526-534. https://doi.org/10.1029/TR027i004p00526

[18] Halford, K.J., Wright, W.D. and Shcreiber, R.P. (2006) Interpretation of Transmissivity Estimates from Single-Well Pumping Aquifer Tests. Groundwater, 44, 467-471. https://doi.org/10.1111/j.1745-6584.2005.00151.x

[19] Krasny, J. (1992) Classification of Transmissivity Magnitude and Variation. Ground Water, 31, 7 p. 